\title{
Broiler Response on Increase in Flour Leaves Miana (Coleus atropurpureus, L) as a Feed Aditive in Ration
}

\author{
Nelzi Fati", Ramond Siregar, Ulva Mohtar Luthfi, Debby Syukriani , \\ Toni Malvin
}

Department of food crop cultivation Agricultural Polytechnic State of Payakumbuh, Indonesia

Nelzifati@gmail.com

\begin{abstract}
Increased bacterial resistance to antibiotics provides a great opportunity to obtain antibacterial compounds by utilizing bioactive compounds from biological natural wealth. In Indonesia there are many known medicinal plants. Miana plants (Coleus atropurpureus, L) are one of the potential medicinal plants in Indonesia. This plant is widely used as medicine. This study aims to determine the effect of adding miana leaf flour to the ration on body weight gain, feed consumption, feed conversion and carcass percentage. This study used a completely randomized design with 5 treatments and 4 replications. The treatment was $\mathrm{A}=$ control, $\mathrm{B}=1 \%$ Miana leaf flour $/ \mathrm{kg}$ ration. $\mathrm{C}=2 \%$ leaf flour miana $/ \mathrm{kg}$ ration, $\mathrm{D}=3 \%$ miana leaf flour $/$ $\mathrm{kg}$ ration $\mathrm{E}=4 \%$ miana leaf flour $/ \mathrm{kg}$ ration. What was observed were performance and carcass including feed consumption, feed conversion, body weight gain, carcass percentage. The results of this study showed that the addition of miana leaf flour in the ration had no significant effect $(\mathrm{P}>0.05)$ on body weight gain, feed conversion, feed consumption and carcass percentage. Giving miana leaf flour in the ration can be tolerated up to $4 \%$ in broiler rations.
\end{abstract}

Keywords : Coleus atropurpureus leaves, antibacterial, carcass, weight gain

\section{Introduction}

The field of livestock industry that is developing at this time, especially poultry, both broiler and laying hens, which in a short time can provide animal protein for human needs. One dilemma in the field of animal husbandry is that the cost of feed covers $70 \%$ of the total production cost. Feeds containing functional components are needed to increase livestock productivity, reduce mortality, improve livestock quality and improve ration conversion rates. To improve all these factors, antibiotics are often used or better known as antibiotic growth promoters (AGP), which function to help fight pathogenic bacteria and can increase livestock productivity. The AGP dose is generally around $2.5-50.0 \mathrm{ppm}$ [1].

Although antibiotics in broiler rations are small in number but have become a special concern of the government and consumers. The European Union has set January 1, 2006 (based on regulation no 1831/2003) a milestone in the elimination of various types of antibiotic use, where over the past several decades these have been substances that are often used by farmers in various parts of the world. As a result of the use of these antibiotics even in low concentrations can increase bacterial resistance and chemical residues and can cause allergic effects in humans. 
Besides that it cannot be denied since antibiotics were given in animal feed as growth promoter compounds, there has been an increase in income from farmers due to the ability of these compounds to convert nutrients in feed efficiently and effectively. The use of antibiotic compounds in rations has become the topic of conversation among scientists, sometimes there is a heated debate due to the adverse effects of consuming livestock products containing antibiotics in animal feed, a result of residues that are still left behind both in eggs, milk and meat. The ban on the use of antibiotics in rations is actually not new to some European countries. The Swedish state in 1986, Denmark in 1995 and Switzerland in 1999 limited the use of additives in animal feed. Increased bacterial resistance to antibiotics provides a great opportunity to obtain antibacterial compounds by utilizing bioactive compounds from biological natural wealth. Bacterial resistance can be transferred from livestock to the human body, through direct human contact with livestock and indirectly through consumption of animal products and food ingredients preserved with antibiotics. In the human body, bacteria will colonize and can cause various health problems, and even cause death. One of the plants that can function as an antibacterial, antioxidant is a miana plant (Coleus atropurpureus, $\mathrm{L}$ ).

Miana (Coleus atropurpureus, L) is an ornamental plant that can be used as traditional medicine from Southeast Asia. The style, shape and color of the miana are diverse, but the medicinal properties are brownish red leaves [2]. Miana leaves contain essential oils, such as antibiotic karvakrol, eugenol is pain relieving, ethyl salicylate inhibits irritation. The leaves also contain alkaloids, minerals and little lenders and appetite enhancers [3].

In an effort to develop and utilize traditional medicinal plants that have been widely used by the community, it is necessary to conduct research to utilize the potential of natural resources that can be used to improve health status, nutrients so as to improve the quality of poultry products free of chemical drugs ( synthetic antibiotics) which results in humans consuming these products.

Research objectives and benefits

The aim of this study :

1. To determine the effect of giving Miana flour to broiler performance and the percentage of broiler carcass.

2. To get the best level of giving Miana flour to broiler performance and the percentage of broiler carcass.

The benefit of the study was to obtain scientific data on miana leaf flour and can also be used as a basis for farmers to improve the performance and percentage of carcass by giving the right miana leaf flour to broilers, which included body weight gain, feed consumption, feed conversion and carcass percentage.

\section{Methods}

This research will be conducted at the UPT Farm and Animal Husbandry Laboratory of the Payakumbuh State Agricultural Polytechnic for 6 (six) months. Livestock. In this study 100 DOC were used without sex segregation. Miana leaf flour. The ration used is commercial ration until the next 1 week chicken stirs its own ration, with a protein content 
of around $22 \%$, an energy content of around $3000 \mathrm{Kcal} / \mathrm{kg}$. The ingredients needed in rations are corn, bran, fish meal, soybean meal, minerals and yellow noodle waste. The cage used is a cage with a size of $60 \times 100 \mathrm{~cm}$ with a height of $60 \mathrm{~cm}$ which each unit consists of 5 tails. Feed scales and Ohaus capacity scales 2 . Blender.

The study was conducted on 100 broilers. The ration used was commercial ration with $22 \%$ protein content, crude fiber below 5\% with 3000 Kcal Metabolic Energy content. A total of 100 DOC broilers were randomly divided into 20 experimental units, each unit consisted of 5 DOCs and each individual was randomly placed in each treatment cage unit. Miana leaves are selected that meet the requirements, the leaves are healthy and not eaten by caterpillars. The leaves are dried and then blended into flour.

\section{Research design}

This study uses a completely randomized design with 5 treatments and 4 replications so that the number of experimental units is 20 units, each of which consists of 5 chickens. As a treatment, there were 5 levels of miana flour in the ration.

The treatment of the level of miana leaves in the ration is:

1. $\mathrm{A}=0 \%$ miana leaf flour in the ration

2. $\mathrm{B}=1 \%$ miana leaf flour in the ration

3. $\mathrm{C}=2 \%$ miana leaf flour in the ration

4. $\mathrm{D}=3 \%$ miana leaf flour in the ration

5. $\mathrm{E}=4 \%$ miana leaf flour in the ration

Table 1. Composition and nutritional content of treatment rations based on calculations

\begin{tabular}{llllll}
\hline Feed ingredients & $\mathrm{A}$ & $\mathrm{B}$ & $\mathrm{C}$ & $\mathrm{D}$ & $\mathrm{E}$ \\
\hline Corn & 48 & 48 & 48 & 48 & 48 \\
Rice brand & 1 & 1 & 1 & 1 & 1 \\
Soybean meal & 37 & 37 & 37 & 37 & 37 \\
Fish flour & 5 & 5 & 5 & 5 & 5 \\
Oil & 3 & 3 & 3 & 3 & 3 \\
Mineral & 1 & 1 & 1 & 1 & 1 \\
Yellow noodle waste & 5 & 5 & 5 & 5 & 5 \\
Total & 100 & 100 & 100 & 100 & 100 \\
Miana leaf flour & & $1 \%$ & $2 \% \mathrm{~kg}$ & $3 \% \mathrm{~kg}$ & $4 \% / \mathrm{kg}$ \\
& - & ration & ration & ration & ration \\
Crude protein & 22,139 & 22,139 & 22,139 & 22,139 & 22,139 \\
Crude fiber & 3,4173 & 3,4173 & 3,1473 & 3,1473 & 3,1473 \\
Fat & 3,9081 & 3,9081 & 3,9081 & 3,9081 & 3,9081 \\
Ca & 0,8504 & 0,8504 & 0,8504 & 0,8504 & 0,8504 \\
P & 0,5912 & 0,5912 & 0,5912 & 0,5912 & 0,5912 \\
Metabolic energy & 3058,9 & 3058,9 & 3058,9 & 3058,9 & 3058,9 \\
\hline
\end{tabular}

Miana leaf flour 
The fresh leaves of the leaves used in this study were obtained from plants grown in the area of Padang Panjang, Municipality of Padang Panjang, Sumbar. Leaf flour is obtained by harvesting +3 months old leaves in good soil condition. The leaves are soaked in sunshine to dry and then folded into flour. The nutritional content of myocardial flour is obtained by the analysis of proximal, $\mathrm{Ca}, \mathrm{P}$ and the active substances contained in myocardial flour. The nutrient composition of leaf flour can be seen in Table 2 .

Table 2. Nutrient composition of Miana leaf flour $(*)$

\begin{tabular}{lc}
\hline \multicolumn{1}{c}{ Nutritional composition } & Miana leaf $(\%)$ \\
\hline Water content & 7,73 \\
Dry weight & 20.33 \\
Rough fat & 1.70 \\
Crude fiber & 35,66 \\
Ash & 12,54 \\
Calcium & 3,29 \\
P & 2,88 \\
Total phenol & $9,08 \mathrm{mg} / 100 \mathrm{~g}$ \\
IC & $282,02 \mathrm{ppm}$ \\
Alkaloids & + \\
Saponin & - \\
\hline
\end{tabular}

Description : * Results of Laboratorium kimia Politeknik Pertanian Negeri Payakumbuh (2017)

To understand the effect of treatment, the data obtained were analyzed with various fingerprints, and continued with the DMRT test if there were differences between treatments.

Parameter measured:

1. Weight gain.

2. Consumption of ration.

3. Feed conversion.

4. Carcass percentage.

\section{Results and Discussion}

\subsection{Weight gain}

The addition of miana leaf flour as feed additive in the ration had no significant effect (P> 0.05) on broiler body weight gain. The average body weight gain during the study as shown in Table 3, Figure 1. The body weight gain of chickens maintained for 30 days of this study ranged from 1,437.00 - 1,467 g / head. Weight gain with the addition of miana leaves with different levels has not affected the resulting body weight.

The broiler body weight gain that was not significantly affected (P>0.05) from the addition of miana leaf flour in the ration, was also closely related to the amount of rations the chicken consumed during the study. During the study the chickens got relatively the same ration, because of iso protein and iso calorie, besides that the health of chicken was almost the same between treatment and normal body condition. Broiler ration consumption is closely related to a number of nutrients that enter the chicken body, the higher the amount of ration consumption, the resulting weight gain will increase, conversely if the value of ration consumption is low then the resulting weight gain will also be low [4]. 
Besides addition to feed factors that support growth, the addition of feed additives. [5] states that the provision of feed additives can help the process of digestion and absorption of nutrients contained in the feed. The mechanism of action of the feed additive is to kill pathogenic microorganisms in the digestive tract, which can kill microorganisms and their crust attached to the intestine. So that this condition causes the intestinal wall to become thinner so that the absorption of food substances increases.

The results of the chemical laboratory analysis of the Agricultural Polytechnic (2018), found that miana leaf flour containing total phenol was $9.08 \mathrm{mg} / 100 \mathrm{~g}$, IC50 that was 282.02 ppm, containing alkaloids, and saponins were not found in miana flour. While the results of research [6], miana leaf simplicia contain a class of terpenoid chemical compounds, tannins (in large quantities), tannin katekat and flavonoids. With the active ingredient contained in miana leaves, it is found that the condition of the chicken to be healthier is evidenced from the level of weight gain that is almost the same for each treatment.

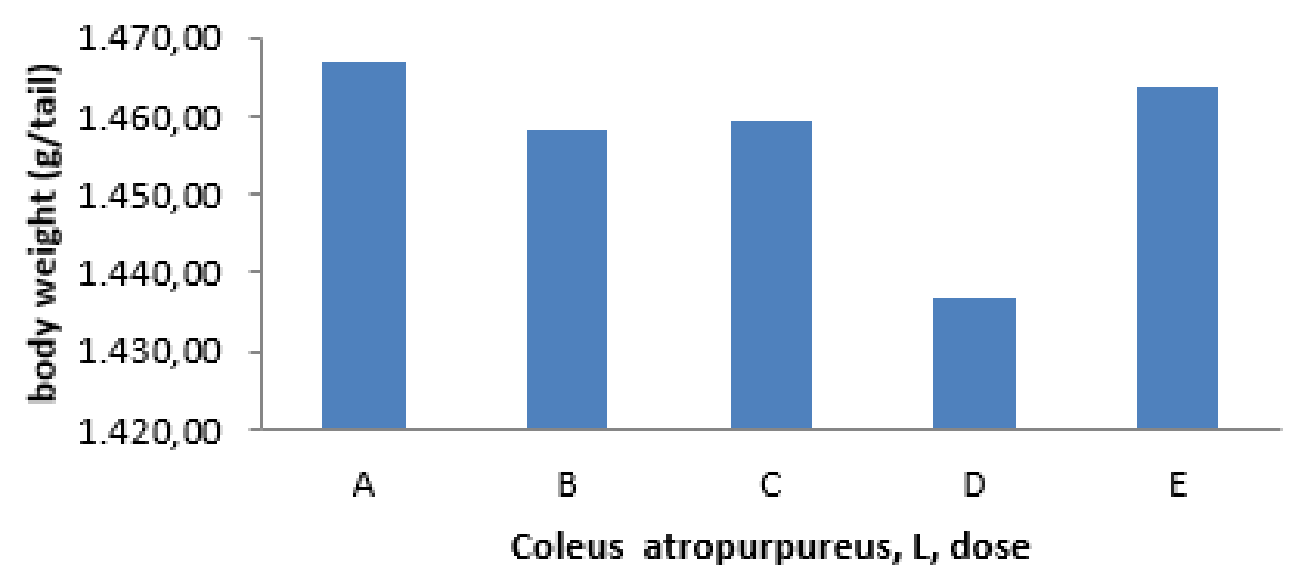

Fig 1. Graphic weight gain (g/tail)

The weight gain produced during the 30 days of this study was $1437.00-1467.00 \mathrm{~g} /$ head. [7] research results obtained broiler body weight gain between $1579.25-1670.75 \mathrm{~g} /$ head / 35 days by giving soursop leaf flour in rations to a level of $3 \%$, whereas from the research results of [8], lower body weight gain of 931.00 - $1003.00 \mathrm{~g} /$ head by giving bay leaf flour (Syzgium polyanthum) in the ration for five weeks of maintenance. The difference in the results obtained is due to different feeds and feed additives that are also different so that it impacts on the resulting body weight.

\subsection{Consumption of Rations}

The addition of miana leaf flour in the ration which functions as feed additive has no significant effect $(\mathrm{P}>0.05)$ on the consumption of broiler ration. Giving miana leaf flour can reduce consumption of broiler rations, compared to without giving miana leaf flour. The highest consumption of ration was in treatment $\mathrm{A}$ (without miana leaf flour in ration), while the lowest consumption was in treatment $\mathrm{D}$ (3\% / kg ration) (Table 3, Figure 2). The low consumption of miana flour is caused by the taste of the miana leaf flour which tends to be bitter, [9] states that chickens do not like feed that tastes bitter, so that at the beginning of 
feeding the consumption is less compared to without miana leaves, after accustomed to consumption will also increase as usual.

The results of this study indicate that the addition of miana leaf flour to $4 \%$ / $\mathrm{kg}$ of rations can still be tolerated against the consumption of broiler rations (Table 3). The addition of miana leaf flour had no significant effect $(\mathrm{P}>0.05)$ on broiler body weight gain and feed consumption. However, increasing the level of addition of miana leaf flour in the ration can numerically reduce the consumption of broiler rannums. According to [5], chicken body condition is closely related to feed consumption, so that it will indirectly have an impact on the performance of the animal itself. [10] research results found that the administration of miana leaves can inhibit the growth of positive bacteria and negative bacteria, this is also supported by [11] research, that miana leaves provide the greatest antibacterial activity, so that the condition of chickens remains good, so that consumption of rats is not significantly different $(\mathrm{P}>0,05)$ between treatments.

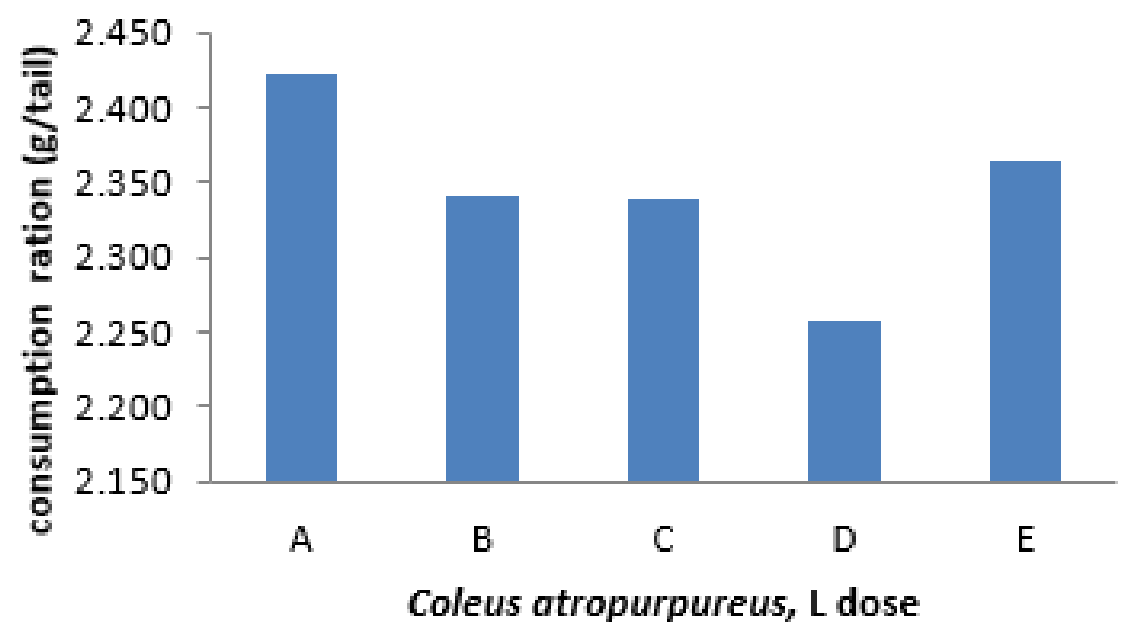

Figure 2. Graph of feed consumption

The addition of miana leaf flour which functions as a feed additive has no significant effect $(\mathrm{P}>0.05)$ on the consumption of broiler ration, which can evaporate during storage so as not to increase the consumption of rations due to the aromatic odor of essential oils, instead can reduce the consumption of broiler rations.

The terpenoid compounds function to help digestion by stimulating the nervous system of excretion, thereby removing the gastric juice containing the enzymes amylase, lipase, trypsin, and pepsin which are excreted into the stomach and intestines. These enzymes function as catalysts in the process of hydrolysis of starch, dextrins, and glycogen to maltose. In addition, these enzymes function as a fat breaker, protein, and peptone [12]. The process of optimizing the digestion of fat and starch results in a low tendency for hunger, thus affecting the consumption of rations. The result is that the consumption of rations is relatively the same between control chickens and treatments.

The consumption of research ration for 30 days was 2257 - $2423 \mathrm{~g} /$ head, while the results of this study were higher than the results of the study of [8], which gave bay leaf flour (Syzygium polyanthum) in rations that also had active components. such as miana leaves, 
which is 2077 - $2163 \mathrm{~g} /$ head / five weeks of maintenance. This is thought to be due to differences in the composition of the ration and leaf flour given to broilers, so that the active ingredient of leaf flour is also different, besides that the increased consumption of rations also impacts on body weight gain, so that the resulting body weight is higher than the results of [8] research..

Tabel 3. Weight gain, consumption ration, feed conversion, and percentage of carcass until the chicken is 30 days old

\begin{tabular}{clcccc}
\hline Treatment & $\begin{array}{l}\text { Weight } \\
(\mathrm{g} / \text { tail })\end{array}$ & gain & $\begin{array}{c}\text { Consumption } \\
\text { ration }(\mathrm{g} / \text { tail })\end{array}$ & $\begin{array}{l}\text { Feed } \\
\text { conversion }\end{array}$ & $\begin{array}{c}\text { Percentage } \\
\text { carcass }(\%)\end{array}$ \\
\hline A & $1.467,00$ & 2.423 & 1,89 & 67 \\
B & $1.458,00$ & 2.341 & 1,79 & 67 \\
C & $1.459,25$ & 2.339 & 1,77 & 66 \\
D & $1.437,00$ & 2.257 & 1,72 & 66 \\
E & $1.463,75$ & 2.365 & 1,77 & 67 \\
\hline
\end{tabular}

\subsection{Feed Conversion}

The results showed that the administration of miana leaf flour had no significant effect $(\mathrm{P}>0.05)$ on ration conversion until the age of 30 days. Numerically, with increasing levels of addition of miana leaf flour in rations, it can reduce feed conversion. Table 3 and Figure 3 shows that the addition of $3 \% / \mathrm{kg}$ ration obtained the lowest ration conversion rate. Table 3 also shows that up to the level of $4 \% / \mathrm{kg}$ of ration supplementation with miana leaf flour can be tolerated by broilers towards feed conversion. The low conversion of rations on the addition of miana leaf flour to $3 \%$ / kg ration, was due to the high body weight gain while the consumption of the ration was small. According to [13], the value of ration conversion is influenced by the body weight gain produced by livestock from a ration unit consumed by livestock. However, giving this miana leaf flour can reduce the conversion rate of the ration compared to the control.

Feed conversion obtained during this study was 1.72 - 1.89 for 30 days of maintenance. [8] research results obtained higher feed conversion, namely $2.07-2.16$, in rations containing bay leaf flour (Syzgium polyanthum) for five weeks of maintenance. While the results of this study are lower than the study of [14] in which the ration was given ethanol extract up to $3 \mathrm{~g} / \mathrm{kg}$ of ration, 2.03 to 2.07 with the same basal feed. The difference in ration conversion is caused by the composition of the ingredients used which is different, the feed additives derived from added leaf flour are also different, so that they contain different active substances, thus impacting on the growth and consumption of the ration which in turn results in different ration conversions. 


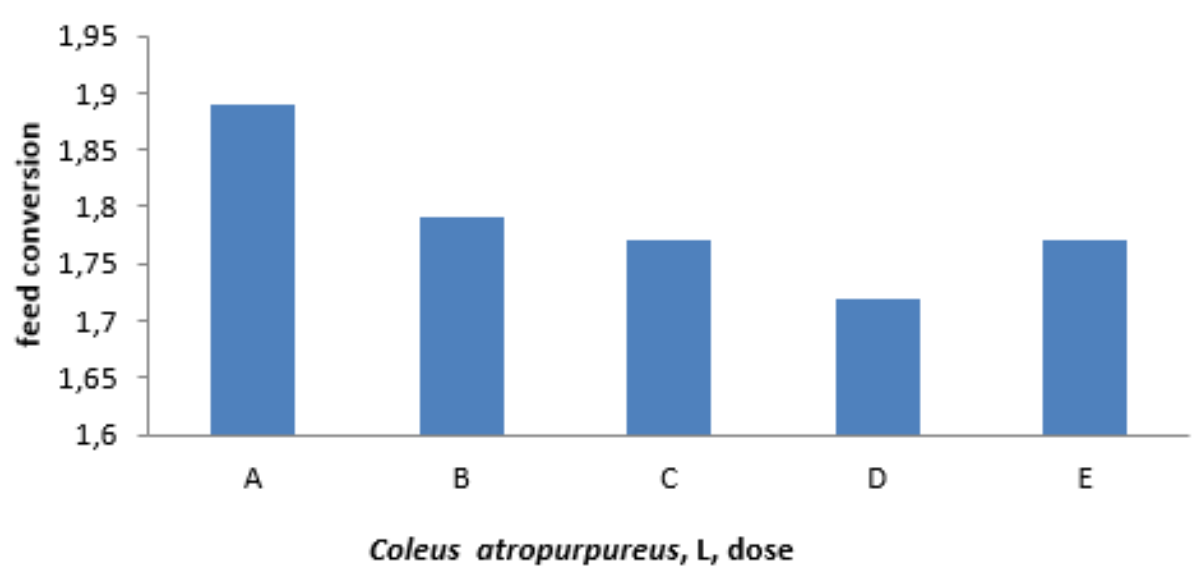

Figure 3. Graph of feed conversion

\subsection{Percentage of Carcass}

The addition of miana leaf flour in the ration did not significantly affect $(\mathrm{P}>0.05)$ on the percentage of carcasses. This means that the addition of miana leaf flour in the ration has no effect on the percentage of carcass (Table 3, figure 4). This is consistent with Nurhayati's (2008) opinion, that carcass production is closely related to body weight and size of broiler carcasses, this difference in carcass is caused by the level of obesity, body size and the level of flesh attached to the chest. Miana leaves also contain essential oil which aims to increase appetite and can improve the digestive tract, but the addition of miana leaf flour to $4 \% / \mathrm{kg}$ of feed has not been able to provide an optimal effect on the weight of broiler carcasses. [10] research results have found that administration of miana leaves can inhibit the growth of gram-negative and gram-positive bacteria. Added again from the results of research [16] that, miana leaves provide the greatest antibacterial activity, so that it can kill harmful bacteria that can cause the digestive process and absorption of nutrients to be more perfect and can improve the digestive tract.

The average percentage of carcasses obtained at the age of 30 days of maintenance is $66.66 \%$ with a range of $66-67 \%$ of the body weight. The average percentage of carcasses obtained by other researchers is $68-71.8 \%$ [16], 56.64\% -60.02\% [17], $68.02-71.03 \%$ [18], $67-68 \%$ [19], 61,30-65,84\% [20], 65,02-66,65\% [21]. 


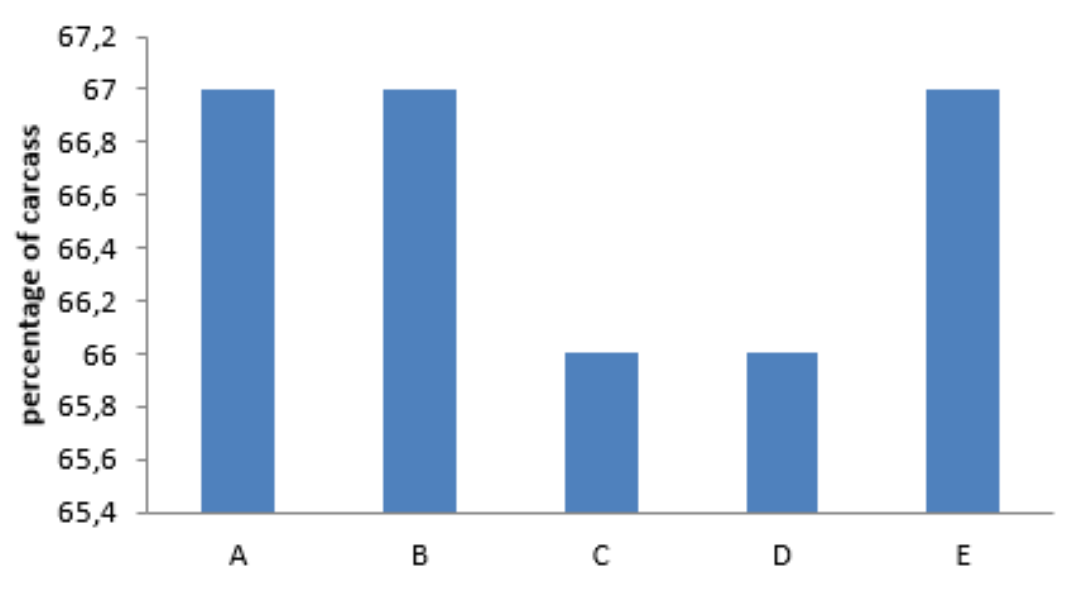

\section{Coleus atropurpureus, L, dose}

Fig 4. Graph of percentage of carcas

The percentage range obtained in this study is not much different from other researchers, this difference is due to the different body weights produced so that the percentage of carcasses is also different, this is influenced by the different feed ingredients given so that it impacts on the growth rate and body composition produced especially at carcass produced. Nutrition factors, age, and growth rate can affect the composition of carcass weight and percentage of carcass which usually increases with increasing live weight of chickens [22]. Carcass production is not only caused by the weight of the cut produced is also influenced by the handling in the cutting process [23].

\section{Conclusions}

From the results of this study it can be concluded that the addition of miana leaf flour to $4 \% / \mathrm{kg}$ ration can be tolerated in the ration towards body weight gain, feed consumption, feed conversion and percentage of carcass

\section{References}

[1] Yanza YR, Szumacher-Strabel M, Bryszak M, Gao M, Kolodziejski P, Stochmal A, et al. Coleus amboinicus (Lour.) leaves as a modulator of ruminal methanogenesis and biohydrogenation in vitro. Journal of animal science. 2018;96(11):4868-81.

[2] Khan TM, Wu DB, Dolzhenko AV. Effectiveness of fenugreek as a galactagogue: A network meta-analysis. Phytotherapy research : PTR. 2018;32(3):402-12.

[3] Nani TF, Mesquita AT, Bustamante Fde O, Barbosa S, Barbosa JV, Davide LC. Variation of karyotype and nuclear DNA content among four species of Plectranthus L' Heritier, 1788 (Lamiaceae) from Brazil. Comparative cytogenetics. 2015;9(4):549-63.

[4] Astuti P, Sudarsono S, Nisak K, Nugroho GW. Endophytic Fungi Isolated from Coleus amboinicus Lour Exhibited Antimicrobial Activity. Advanced pharmaceutical bulletin. 2014;4(Suppl 2):599-605.

[5] Widodo, W. 2002. Nutrition and contextual poultry feed. Improvement of Higher Education Research Project at the Ministry of National Education. Faculty of Animal Husbandry-Fisheries, Muhamadiyah University, Malang. 
[6] Lisdawati, V., D. Mutiatikum., S. Alegantina dan Y. Astuti. 2008. Karakteristik daun miana (Plectranthus scuttellariodes (L) Beth) dan Buah sirih (Piper betle, L) secara fisikokimia dari ramuan lokal antimalaria daerah Sulawesi Utara. Media Litbang Kesehatan Volume XVIII nomor V. tahun 2008. p 213-225.

[7] Simanjuntak. M. C. dan P. Patabo. 2016. Pengaruh pemberian tepung daun sirsak (Annona muricata, L) dalam pakan terhadap berat organ dalam ayam pedaging (broiler). J. Agroforestri. XI (1). Maret 2016.

[8] Wiryawan, K. G., S. Luvianti., W. Hermana, dan S. Suharti. 2007. Peningkatan performa ayam broiler dengan suplementasi daun salam (Syzygium polyanthum (Wight)Walp] sebagai antibakteri Escherichia coli. Media Peternakan, Vol. 30. No.1. hal 55-62.

[9] Glasgow L, Forde M, Brow D, Mahoney C, Fletcher S, Rodrigo S. 2019. Antibiotic Use in Poultry Production in Grenada. Veterinary medicine international.:6785195.

[10] Ebsa YA, Harpal S, Negia GG. 2019. Challenges and chicken production status of poultry producers in Bishoftu, Ethiopia. Poultry science.

[11] Mojahed Asl L, Saleki K, Nemati M. Comparison of Relation between Resistance Pattern to Erythromycin and Tetracycline and the Prevalence of Superantigens Coding Enterotoxins A and B in Staphylococcus aureus Isolated from Broiler Poultry in Ilam, Iran. Archives of Razi Institute. 2019;74(2):157-64.

[12] Shi Z, Rothrock MJ, Jr., Ricke SC. Applications of Microbiome Analyses in Alternative Poultry Broiler Production Systems. Frontiers in veterinary science. 2019;6:157.

[13] Caucci C, Di Martino G, Dalla Costa A, Santagiuliana M, Lorenzetto M, Capello K, et al. Trends and correlates of antimicrobial use in broiler and turkey farms: a poultry company registry-based study in Italy. The Journal of antimicrobial chemotherapy. 2019.

[14] Benzertiha A, Kieronczyk B, Rawski M, Kolodziejski P, Bryszak M, Jozefiak D. Insect Oil as An Alternative to Palm Oil and Poultry Fat in Broiler Chicken Nutrition. Animals : an open access journal from MDPI. 2019;9(3).

[15] Fati, N., R. Siregar and Sujatmiko. 2017. Respon broiler terhadap pemberian ekstrak Etanol daun bangun-bangun (Coleus amboinicus, L) dalam ransum. Proseding Seminar Nasional Keberlanjutan Pertanian Indonesia, Tantangan dan Peluang Menuju Peningkatan Daya Saing Global, Politeknik Pertanian Negeri Payakumbuh.

[16] Fati, N., Siregar, R., \& Sujatmiko, S. J. L. (2018). Pengaruh Pemberian Ekstrak Daun Bangun-Bangun (Coleus Amboinius, L) Terhadap Persentase Karkas dan Organ Fisiologis Broiler. 17(1), 42-56.

[17] Fati, N., Siregar, R., \& Sujatmiko, S. J. E. B. I. B. M. (2019). Addition Of Coleus Amboinicus, L Leaf's Extract In Ration To Percentage Of Carcass, Abdominal Fat, Liver And Heart Broiler. 20(1), 1-9.

[18] Murugesan, G.S., M. Sathishkumar, \& K. Swarninathan. 2005. Supplementation of waste tea fungal biomass as a dietary ingredient for broiler chicken. Biores Technol. 96: 1743-1748. 